\title{
Correction to: Smart controlled environment agriculture methods: a holistic review
}

\author{
S. Ragaveena · A. Shirly Edward • U. Surendran
}

Published online: 21 October 2021

(C) Springer Nature B.V. 2021

Correction to: Rev Environ Sci Biotechnol

https://doi.org/10.1007/s11157-021-09591-z

The correct affiliations of co-authors S. Ragaveena and A. Shirly Edward are given below,

Department of Electronics and Communication Engineering, College of Engineering and Technology, SRM Institute of Science and Technology, Vadapalani Campus, Chennai, India

The original article can be found online at https:// doi.org/10.1007/s11157-021-09591-z.

\section{S. Ragaveena · A. S. Edward}

Department of Electronics and Communication Engineering, College of Engineering and Technology, SRM Institute of Science and Technology, Vadapalani Campus, Chennai, India

\section{U. Surendran $(\bowtie)$}

LWMRG, KSCSTE, Centre for Water Resources,

Development and Management, Kozhikode,

Kerala, India

e-mail: u.surendran@gmail.com
Publisher's Note Springer Nature remains neutral with regard to jurisdictional claims in published maps and institutional affiliations. 